\title{
Significance of cultural values in securing asset portfolios of rural communities
}

\author{
Chandima D. Daskon* \\ National Centre for Peace and Conflict Studies, University of Otago, Dunedin, New Zealand.
}

\begin{abstract}
Cultural values play a significant role in the context of rural livelihoods. Rural livelihoods are fundamentally determined by the capabilities of people and their cultural practices, values, norms, customs, knowledge and belief systems that are preserved through generations. The aim of this paper is to understand and explore the intricate relationship between livelihood assets and local cultural values with respect to building secured asset portfolios of rural communities. Empirical evidences are drawn from field research undertaken in 2008/09 in rural villages in Kandy, Sri Lanka. The ways in which villagers construct their livelihoods in their villages are multiple and there are significant traditional components, which facilitate their resource accessibility and ownership. Cultural traditions are treated as a resource that strengthens social assets and the solidarity of villages. Although the opportunities may be fewer, traditional skills and knowledge are considered important as a source that strengthens human assets. Locally shared cultural values and norms also play a significant role in defining community problems. However, the extent to which cultural values facilitate and impede asset entitlement may vary among communities. The paper recognises culture as a capital asset which is fundamental in building a secure and sustainable asset portfolio, encompassing all tangible and intangible values embedded in human society, enabling and empowering rural people.
\end{abstract}

Keywords: Culture, capital, livelihoods, rural communities

\section{INTRODUCTION}

Although efforts have been made elsewhere to demonstrate the link between culture and development (Rao \& Walton, 2004; Schech \& Haggis, 2000; Commonwealth Foundation, 2008), there has been little recognition of the significance of culture in the context of achieving sustainable rural livelihoods (Daskon, 2010 $\&$ 2011). The role of local culture in fostering a complete understanding of rural community development has received relatively less attention in empirical analyses.
Traditionally, the contribution of culture is analysed on a nation-wide basis and there has been less focus on the importance of cultural values in the everyday life of people and in building community identity at the local level. As Brennan et al. (2009) argued, culture continues to be viewed as an outgrowth of a particular region, which suppresses culture's role in shaping community debate and action. The current development literature and livelihood analyses do not provide researchers and practitioners with clear guidance on the way in which cultural aspects might be appropriately incorporated into the development process and sustaining livelihood systems of rural communities. Analysing the significance of cultural traditions in relation to rural livelihood systems, Daskon $(2010 ; 2011)$ concludes that culture is a fundamental phenomenon that plays a crucial role in strengthening livelihood assets, livelihood resilience, livelihood security and sustainability of rural communities. Most rural communities possess their own customs, heritage, values and knowledge systems that affirm identity and diversity, and play a key role in sustaining their lives.

In the livelihood context, five types of assets are discussed, including social capital, human capital, natural capital, physical capital and financial capital ${ }^{1}$ (Figure 1). These assets are regarded as synonymous with resources or 'capital' that can be used to build a sustainable livelihood, (de Haan, 2000). Referring to Hebinck \& Bourdillon, Adato \& Meinzen-Dick (2002) argue that in considering livelihood framework, an overreliance on the concept of 'capital', over emphasises the material aspects of people's lives. Despite this unsettled intricacy of the notions of 'assets' and 'capital', it is argued that secure ownership and accessibility to the above listed assets are foremost in attaining a sustainable livelihood (DFID, 1999). However, these assets are 
entirely economic representations without signifying the important nature of people's inner knowledge, their genuine capabilities and more importantly, the aspects of culture, identity and traditional values. People undertake different livelihood activities through the combination of different assets available to them. A proper understanding of the types of assets available and asset accessibility enables an exploration of what people really possess rather than what they do not have. Therefore, it is suggested that a closer investigation of the ways that people build and maintain their household asset portfolios with the help of their societal and cultural values, is vital, before making an early conclusion that rural underdevelopment is a matter of material deficiency or lack of capacities. The evaluation of rural assets through a cultural perspective provides a valuable and nuanced understanding of what a community's genuine strengths and resource endowments are and how these are, or might be, converted into sustainable livelihood outcomes.

The purpose of this paper is to investigate the links between livelihood assets and local cultural values with respect to building and securing asset portfolios of rural communities, drawing upon field research undertaken in rural villages in the vicinity of Kandy, Sri Lanka. The village communities selected for the study mainly engage in traditional craft industries that have been maintained for centuries. Their livelihoods are fundamentally determined by their own skills and knowledge and more importantly, the 'existing' tangible and intangible resources, with the latter essentially representing the values, norms, customs and knowledge systems that are traditionally embedded in their societies. There is clear evidence to argue that these communities engage extensively with their cultural resources and utilise their cultural values to access various capital assets and to pursue sustainable livelihood outcomes. The research data explains how cultural traditions strengthen or weaken villages' asset portfolios in terms of their availability, accessibility and assets entitlement. Based on the culture-asset relationship, this paper argues that livelihood assets are not mere 'resources', which assist people to build and secure their livelihood portfolios, but are vital in providing identity, pride, self-esteem, meaning, belonging and social cohesion, as well. The absence of an adequate cultural analysis is a serious shortcoming in current livelihood studies and the research underlined in this paper sets out to bring an improved understanding of the significance of a cultural perspective at every stage of rural livelihood analysis. This paper argues that cultural traditions are fundamental in forming livelihood assets in the Kandyan context, and proposes a new form of asset cultural capital - where cultural values can be explicitly treated as a resource. It is recognised that this study is just one example, yet there are significant findings that should be considered in relation to the wider relevance of cultural capital for other rural villages across the country and beyond, with equally strong cultural traditions.

\section{LIVELIHOODS, ASSETS AND CULTURE}

Development analysis has often assumed that culture and traditions inhibit entrepreneurship and constrain development interventions and hence, there has been a failure to appreciate the complex interaction between economics and culture (Jenkins, 2000; Throsby, 2001). With its global models, broad theoretical abstractions and reliance on hypothetical analyses, the underlying assumption was that development is a placeless process which has 'no' cultural context and can be implemented anywhere, irrespective of local diversity (Tucker, 1999). However, grassroot movements and post-development approaches criticise such 'Eurocentric' biases and attempt to legitimise cultural values as a prerequisite for attaining sustainability within communities. For instance, Chambers' (1998) proposition of "putting the last first" and his book "Challenging the professions: frontiers for rural development' provoked a new way of thinking of people, culture and local values and provided a coherent and mutually supporting pattern of concepts, methods and actions, amenable to wider application. The concepts, such as self-reliance, basic-needs, grassroots movements, bottom-up, participation, partnership, people-centred and sustainability have been articulated within a broader alternative paradigm, bringing the 'last' into the 'first' with new ethics in development knowledge and shifting development focus from 'things' to 'people' (Chambers, 1998).

The sustainable livelihood approach (Figure 1) originated from this background as a branch of alternative paradigms. It represents complex ideas and interests associated with poverty, participation and structural and institutional processes, over which a number of development debates have been contested during three decades (1970s-2000s) (Ellis \& Biggs, 2001). In development, the concept of sustainable livelihoods has become popular, emerging from grassroots critiques of macro-development theories and has been adopted, with growing legitimisation, through several major international forums (Carney, 1998) ${ }^{2}$. The approach provides a set of guiding principles that summarise the effective ways of planning, implementing and evaluating development initiatives at the ground level.

Chambers \& Conway (1991) introduced the concept of 'sustainable livelihood' with the following working 


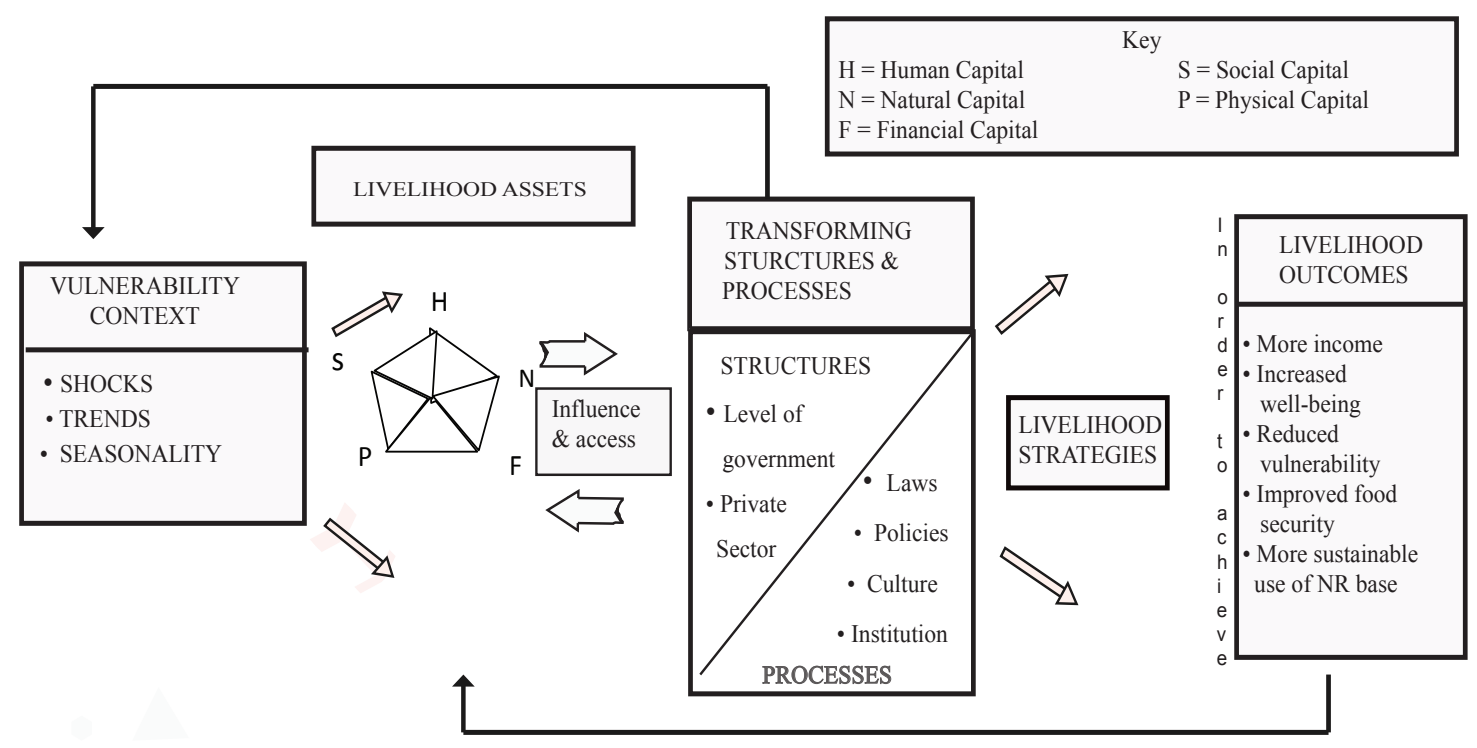

Figure 1: Sustainable livelihood framework

Source: DFID (1999)

definition, which became a major source of inspiration in present livelihood research.

"A livelihood comprises the capabilities, assets and activities required for a means of living; a livelihood is sustainable when it can cope with and recover from stresses and shocks, and maintain or enhance its capabilities and assets, and provide sustainable livelihood opportunities for the next generation; and which contributes net benefits to other livelihoods at the local and global levels and in the short and long term".

In a broader perspective, however, livelihood should go beyond the material well-being and economic concerns of life. It should also represent the non-material aspect of human well-being (Daskon, 2011). By quoting Wallmann (as cited in Appendini, 2001), de Haan \& Zoomers (2003) assert that, livelihood is equally a matter of ownership and circulation of information, the management of skills and relationships and affirmation of personal significance and group identity. Thus, livelihood is necessarily a dynamic and holistic concept that encompasses both material and non-material fulfilment of human lives.

The ability to pursue different livelihood strategies depends on the basic material (tangible) and nonmaterial (intangible) assets that people have. These assets, according to Bebbington (1999), are not merely means with which people make a living, but they also give meaning to their world. Thus,

"assets are not simply resources that people use in building livelihoods; they are assets that give them the capability to be and to act".

The conventional livelihood approach is based on livelihood assets, knowledge of which is fundamental to understanding (a) resources and options open to people; (b) strategies to help them attain a sustainable livelihood; (c) outcomes they aspire to; (d) the vulnerability context under which they operate (Chambers \& Conway, 1991; Carney, 1998; Moser, 1998; Scoones, 1998; Ellis, 2000). Thus, livelihood assets are considered an integrated element with all other components in the framework.

One of the criticisms of the rural livelihood approach is that its simplistic representation of the reality and complexity of livelihood systems has ignored the relative importance of such crucial aspects and the relationship between them (Bebbington, 1999; Adato \& Meinzen-Dick, 2002; Cahn, 2002; Glavovic et al., 2002; Toner, 2003). An inadequate consideration of the cultural perspective oversimplifies not only people, but also their resourcefulness and capacities and thus, the complexity and diversity of resource entitlement and livelihood opportunities. If culture is focused on, along with policies, institutions 
and processes, the concept does not stand as an allencompassing entity. Culture is understood as a rigid structure that controls communities' accessibility to available assets and livelihood choices (see DFID, 1999). The rural livelihood approach's weak version of culture (e.g., gender, ethnicity, class) is often referred to as an obstruction in advancing people's livelihood choices and accessing livelihood assets. In such a sense, as Eames (2006) argued, culture represents communities that are highly hierarchical and intolerant of external threats and internal diversity. Their ideological structures are rigid and free enquiry or research is discouraged.

The concept of culture is used in a variety of contexts to mean many different things and generally refers to the customs, practices, languages, values and world views that define social groups, such as those based on nationality, ethnicity, region or common interests. Development agencies have favoured broad definitions of culture, with UNESCO (2001) claiming that culture is "the total and distinctive way of life of people or society". According to McNulty (1991) and Weiler \& Hall (1992) (as cited in MacDonald \& Jolliffe, 2003), family patterns, folklore, social customs, museums, monuments, historical structures and landmarks are significant elements of culture. Culture can be understood as an entity that represents structures, functions, ideologies, products and power relations in society (Daskon, 2011). Hence, culture, is a complex, diverse and vigorous variable that shapes people's livelihood choices and asset endowments. Therefore, it calls for an advanced approach, rather than that of the limited and unenthusiastic interpretation within policies and development processes. Thus, in a livelihood context, analysis of culture must go further in enquiring how cultural values influence people's decision-making processes, representation, identity making, resource ownership and accessibility, social relations and overall livelihood sustainability; how culture 'facilitates' resource accessibility rather than 'controls' resource ownership. The livelihood approaches have further potential in incorporating and better informing the 'positive' roles of cultural values in the context of achieving livelihood sustainability. The approach is capable of prioritising people, their values, traditions, knowledge and capabilities through their own perceptions and definitions. Cultural traditions should be regarded as a key resource for sustainability of rural livelihoods and the narratives of this paper support this proposition.

\section{SRI LANKAN RURAL VILLAGE, CULTURE AND HERITAGE}

Sri Lanka is a land with a rich cultural heritage that spans over a recorded history of 2600 years. The country's vibrant cultural traditions can be interpreted through famous ideological and symbolic expressions, such as Dhaammadvipa (land of justice), Sinhaladvipa (land of the Sinhalese), 'Granary of the East', wewa (village tank), dágaba (pagoda) and ketha (paddy field). Once the country had a prosperous and harmonious civilisation, which was village-based, self-sufficient, ecologically sustainable and more significantly, culturally integrated (Hennayake, 2006; Brow, 1999; Moore, 1989; Leach, 1961; Coomaraswamy, 1956). Brow (1999) for example, refers to Kemper (1991) and recognises that the rural village communities are living in "peaceful co-operation with one another according to Buddhist precepts and ancient customs". With specific reference to the Kandyan craftsmen, Coomaraswamy (as cited in Brow, 1999) describes village life as "one of great simplicity", but also one of dignity, serenity, and leisure, in which congenial work and personal appreciations were highly valued. However, Brow (1999) refers to Bandaranayake (1980) and Lipsey (1977) and criticises Coomaraswamy's interpretation of village life as they were largely drawn from the reports of early observers such as Knox, D’Oyley and Gieger ${ }^{3}$. Thilakasiri (1994) provides a comprehensive picture of the present day life among rural (craft) communities in the country. However, traditional rural economies and social practices exist beside modern economies and the majority of the population lives in rural areas relying predominately on the traditional agricultural sector for a living. Rural villages in the country are regarded as a 'living heritage', blurring traditional and modern distinctions.

\section{METHODOLOGY}

\section{Study area}

The present Kandy District comprises of 20 Divisional Secretariats (DS) and 2987 villages (Department of Census \& Statistics [DCS], 2001). Total district population is about 1.4 million (as of 2006) (DCS, 2006/07) and $80 \%$ of them live in rural areas; $12 \%$ is in urban areas and remaining $8 \%$ is in the estate sector. Due to its historical and cultural significance, Seneviratne (1983) refers to Kandy as the 'cultural capital' of Sri Lanka. It has also been regarded as a 'heaven' for its spectacular natural, architectural, historical, artistic and cultural features (Crick, 1994; Duncan, 1990). Traditional arts and crafts and the traditional craft communities such as dancers, drummers, painters, jewellery makers, ivory and wood carvers, lac workers and Dumbera weavers form a distinctive Kandyan identity. Kandy was designated a world cultural heritage site by UNESCO in 1988.

Field research was undertaken in five villages in Kandy; namely, Kiriwaula, Embekke, Talagune, 


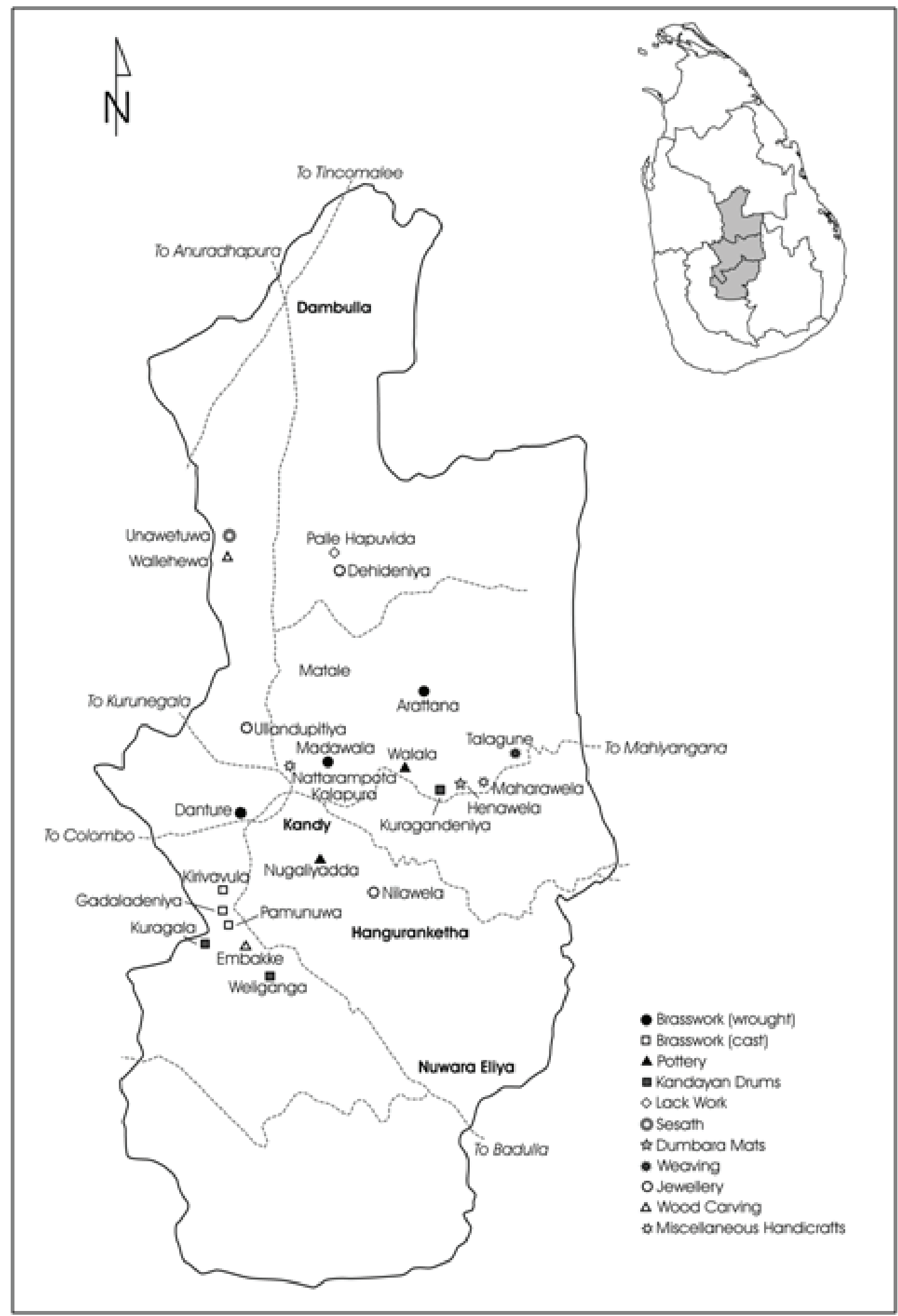

Figure 2: Distribution of craft villages in the Central Highland Region, Sri Lanka 
Kalapura and Henawala (Kalasirigama) in 2007 and 2009 (Figure 2). These villages are typical of rural communities in the region and well known for their distinguished industries in traditional handicraft that have thrived for generations. Generally, the lives of rural Kandyans are centred on paddy farming, while hereditary craft industries also play a vital role in their lives. There are about 650 families in these villages currently engaged in craft and craft related industries. Kiriwaula and Embekke are renowned as areas specialising in traditional brassware and wood carving respectively. Talagune is famed for traditional Dumbera weaving and is the last remaining weaving village in the country. Kalapura is a 'colony' of traditional craft families established under the 'Gam-Udàwa' scheme. Earlier, Henawala (Kalasirigama) was renowned for mat weaving, but today a majority of its families engage with drum making industry. The majority of the research participants are regarded as descendants of the distinguished traditional craft families.

A majority of the study communities belong to the 'Navandanna' (knowing 'nine' types of crafts) or the 'artist' caste, and they trace their ancestry back to their great grandparents who worked during the period of the Kandyan kingdom $\left(16^{\text {th }}-19^{\text {th }}\right.$ century $)$. Traditionally, many of them were commissioned to execute work specifically for the Temple of Tooth and other sacred temples around Kandy (Coomaraswamy, 1956; Seneviratne, 1978). As Coomaraswamy (1956) explains, and also revealed from field investigation, members of the 'Navandanno' group were/are held in high esteem, with outstanding craftspeople working solely for the royal household and forming a closeknit body of hereditary groups known as the 'Pattalhatara'- 'four workshops'. Based on the connectivity between traditional caste system and occupation, there are different groups of people in these villages, namely silversmiths, brass workers, wood carvers, weavers, painters, jewellers, tom-tom beaters and dancers. Although these 'caste divisions' and 'caste-based activities' are not formally functioning in present day village society, the traditional professions assigned by the ancient caste system are still observable in these villages and especially, during cultural events like the 'Daladá Perahara's. As Thilakasiri (1994) revealed, although the number of craft families may change from generation to generation, they have a longstanding connection with their traditional villages and lifestyles. However, due to the rapid social and economic transformations, rural lifestyles have changed considerably and most of these traditional livelihoods are under pressure as they have no satisfactory market and regular raw material supply. Therefore, most of these villages remain underdeveloped.

\section{Research approach}

Recent livelihood studies provide a wealth of sources and guidance for selecting appropriate methods for the present analysis, varying from quantitative \& qualitative approaches to mixed methods approaches (Bagchi et al., 1998; Pasteur, 2001; Bond \& Mukherjee, 2002). For this study, a purposive sampling technique ${ }^{6}$ was employed to select information-rich participants, referring to six criteria described by Miles \& Huberman (1994). Reported data on village assets are too little and some preliminary information on the villages, livelihoods and asset portfolios was gathered through secondary field reports, books and documents published by the government and non-government institutions and departments. Based on methods described by a number of authors (Shivakoti \& Shrestha, 2005; Sreedevi, 2005; Pasteur, 2001; DFID, 1999), participatory research techniques, including preference ranking and transect walks, were employed, along with other qualitative methods. Transect walks were systematically carried out with the help of key village informants, specifically to observe and understand the availability, quality and accessibility to different livelihood assets, particularly physical and natural assets in each village. The methods encouraged the active involvement of villagers in exploring their own resources, development potentials and problems as experienced in an everyday context. Villagers participated in a ranking exercise in order to identify the relationship between livelihood assets and local cultural context. As many researchers have experienced, ranking exercises are a powerful way to represent relatively complicated sets of data in a manner that is clear to both the researcher and to local participants. During the ranking exercise, the five asset categories and their characteristics were thoroughly explained by using different indicators/variables, for the village participants who were selected after considering the nature of livelihood activities, gender and age structure. The village participants were then allowed to recognise asset status and to use their own indicators and definitions particular to their village context to characterise each asset category. The in-depth interview was one of the principle techniques used to gather villagers' perceptions of asset relations. In the development research context, in-depth interviews are useful in empowering participants and in democratising the research process, allowing participants to speak for themselves, and then to interpret the data they produced. As DFID (2001) has experienced, key informant interviews were also useful, particularly for analysing village livelihoods, and the key informant interviews conducted in this study provided in-depth information on local resources, including the incidents that cause asset vulnerability. These qualitative techniques were 
useful in gaining powerful insights into social meanings that cannot be measured or quantified (Brockington \& Sullivan, 2003), and help to answer particular issues related to livelihood assets and the cultural context. From a development researcher's perspective, such qualitative techniques are important for understanding how the researcher and the research become part of other people's lives (Flick, 2006).

\section{RESULTS:LIVELIHOOD ASSETS, OWNERSHIP AND ACCESSIBILITY AT VILLAGE LEVEL}

\section{Social capital - support from the village communities and families}

Social capital is one of the foremost asset endowments of a sustainable livelihood. It consists of,

"rules, norms, obligations, reciprocity and trust embedded in a society that enable its members to achieve their individual and community objectives" (Narayan \& Pritchett, 1997).

Putnam (2000) defines social capital as "social networks and the norms of reciprocity and trustworthiness that arise from them". As described in livelihood literature, social capital is a 'social resource' (Carney, 1998; Scoones, 1998), and it refers to networks and interconnectedness ${ }^{7}$, membership of more formalised groups ${ }^{8}$ and relationships of trust, reciprocity and exchanges ${ }^{9}$ (DFID, 1999 \& 2001). Chambers \& Conway (1991) describe social assets as part of the 'claims' that facilitate people's accessibility to other livelihood assets. These claims are made on individuals or agencies, relatives, neighbours, social groups, communities and NGOs, government organisations and on the international community. In this sense, social capital represents all social relations at individual, household and community levels and therefore, it is a 'relational concept'.

Village data shows that social capital is a significant asset among the village communities, and it consists of various attributes. Villagers referred to different societies, such as 'Samurdhi', Village Craft Society, Welfare Society, Funeral Aid, 'Prajá Sanwardena Samithi' (Community Development Society), Cooperative, Women and Youth Society, and to other different groups/institutions, including relatives, friends, neighbours and labour networks, like 'attam', as significant sources of social capital in their villages. As revealed during the village interviews, there are two types of social assets, formal social capital (FSC) and informal social capital (ISC). Most of the above societies are recognised as sources of formal social capital and are operated through formal membership and commonly-accepted rules, regulations and procedures. They influence the livelihoods of villagers in various ways, strengthening and sometimes weakening their livelihood activities. Some of the institutions are directly engaged in the task of livelihood development while others undertake supporting roles. Village Craft Society, for example, is considered an important 'social asset' and, as one villager clarified:

"The Society supports our traditional industries ('páramparika karmantha'). It encourages our participation in the national exhibitions and widens new market opportunities too."

These societies are also regarded as important in relation to the collective achievements of villagers and decision-making regarding the development of village infrastructure and mobilisation of raw materials, labour and financial resources. However, accessibility to the benefits of a craft society is conditional on society 'membership', which is mandatory for everyone who engages in traditional craft industries. This was clarified by a participant:

"We should keep our membership ('samajikathwaya') to get benefits from the society. Non-members don't receive any benefits."

Almost 90 percent of the families who engage in such industries have society membership. However, some villagers are disappointed about the way some societies operate. One respondent explained this as follows:

"Priority should be given according to the type of industry, experience and craftsmanship. But we don't know how the beneficiaries are selected. So, the Society is not always helping people".

This comment was a veiled reference to village politics and the villagers' preferences, affiliations and alliances with such formal institutions. The trustworthiness of such formal institutions is rapidly deteriorating.

Relatives, neighbours, friends and labour networks are some of the significant sources of social capital in these villages and they have organised as 'informal' social units. Morris (1998) refers to them as 'informal social capital', which represents 'informal networks' that operate outside the formal institutions. Such sources operate through their family customs and cultural norms, thus they are purely 'mental', and Uphoff \& Wijayaratna (2000) describe them as 'cognitive social capital'. Field data confirms that a majority of the villagers rely on their 
relatives and neighbours often, and are more satisfied with their support and courtesy than with any support received from formal institutions operating in their villages. For example, one villager asserted that: "There are various Societies in this village, but they are useless as they don't help people when required". Villagers have established strong relationships with their neighbours and relatives through the family norms and obligations that have been maintained and handed down from generation to generation. Such informal assets are almost an 'inherent resource' that strengthens the mutual trust and reciprocity among villagers and are useful in dealing with everyday livelihood issues. Particularly in these contexts, villagers rely more on informal social assets, rather than the formal institutions to deal with their everyday problems. For example, a female respondent explained the importance of informal networks for retaining her livelihood by:

"I was desperate since my husband died. But, my relatives ('neadáyo') and neighbours ('ahalapahala aya') help me with different things. Very often, I borrowed money from them. I don't think anybody gets such a support from any of the 'so-called' Societies, when they [are] needed."

Her comment reveals that the village Societies that have been formed to assist families when they lose a breadwinner, have not given her any assistance. In this context, informal social relations are foremost in securing her livelihood assets such as financial and physical assets. As a long-established custom, the members of her family extend their co-operation in the performance of various duties towards her. This occurs because of the values, norms, customs and attitudes attached to her family. This co-operative spirit is an exemplary feature that tightens not only family ties, but also village solidarity.

Another villager referred to their heritage ('párampara urumaya') to clarify the nature of their social relationships:

"This land is inherited from our great grandfather, and we all live here by sharing this land. We don't want to separate by splitting the land, which is against our family custom".

During the field observations and transect walks, it was clear that many of their houses were in compounds without clearly demarcated borders or fences around their houses. Another respondent asserted that: "Although we are not under one roof, we are all in one compound. We work together and help each other". Even though the general layouts of these villages have changed over past decades, it is clear that the 'shared compound' is a feature that has remained unchanged for many generations. In such a neighbourhood environment, labour networks, like 'attam', are obvious, and it is an informal institution that normally operates purely through the 'mutual trust and reciprocity' of village people. This gives them an opportunity to use their labour in a roster manner (Karunanayake, 1979) ${ }^{10}$. Although 'attam' in these villages does not exist in the precise 'traditional' manner, according to villagers' perceptions, 'attam' in their villages operates on the basis of mutual feelings about their commonality created by their castes, systems of beliefs, norms, family customs and ancestral relationships. This mutual labour pooling helps villagers to connect with each other and to strengthen their social integration for the purpose of adaptation and survival during times when they have difficulties (Karunanayake, 1979). Respondents believed that these relationships are effective, especially in the times of livelihood vulnerability, by increasing accessibility to other livelihood assets through collective actions, which reduce their transaction costs.

\section{Human capital - people's strengths, skills and capabilities}

In the livelihood context, both the quantity and quality of human capital, in particular labour available to households, are most important and vary according to household size, skills, leadership potential and health status (Carney, 1998; DFID, 1999; Rakodi, 1999; de Haan, 2000). Human capital comprises of skills, knowledge, ability to work and good health to enable people to pursue different livelihood strategies and achieve their livelihood objectives (DFID,1999). Among rural communities, family labour is the chief form of human capital (Ellis, 2000). In the village examples, there are no significant variations in the overall situation of human assets among the study communities. They all possess higher levels of human capital. In the study villages, human capital noted by the participants includes a ready access to traditional knowledge, ('páramparika danuma') skills ('shilpa'), quality and quantity of household labour and, in general, willingness and determination to work hard to sustain their livelihoods. To better understand the human capital profile and its linkages with cultural traditions, human capital can be examined under two sub-themes: education and household labour.

\section{Level of education, skills and knowledge}

When considered as a whole, in every village, there was a consensus among respondents that most of their knowledge and skills originated from their ancestors. For example:

"This skill (shilpaya) is a gift from our forefathers ('muttun-mittan'). We are thankful to them for 
preserving these valuable skills and handing them down to us".

In terms of quality and quantity, traditional knowledge is regarded as being more effective and useful, particularly with respect to their current livelihood activities, and as clarified by a village silversmith:

"our knowledge is practical 'Ape danuma práyogikai' and not recorded anywhere. We have been practising these skills from the beginning".

It is interesting to note that villagers are not passionate about formal education, as neither formal education nor training is required or useful for these people in maintaining their 'current livelihoods'. According to the majority of the respondents, the specialised knowledge and skills needed to pursue their livelihoods are generally unattainable through formal education. They have learned all the basic techniques required for their livelihoods from their grandparents and this was explained by one wood carver:

"Our grandparents guided our 'hands' from the beginning. We first learned 'Vaka-Deka'. That is the basic motif of all traditional designs. It teaches us how to control our hands. Then, we learned intricate motifs with time ${ }^{11}$. These designs are unique to us and have been passed on for generations".

The older members of the villages, those who possess more than 30 to 40 years of experience in their livelihoods, are confident in their traditional knowledge ('páramparika danuma') and its incompatibility with modern knowledge and skills. They believe that the knowledge and skills they use today are not that different from those used by their predecessors. However, the younger villagers' perceptions of traditional knowledge are somewhat different to those of the elderly villagers:

"No doubt that traditional knowledge is a great 'asset' we have. But, we can't rely on this alone. We should also have extra knowledge ('amathara denuma') and training ('puhunuwa') to adjust our lives".

Formal education and vocational training were given a higher priority than traditional knowledge by some villagers in considering the sustainability of the younger generations' livelihoods. However, there is a consensus among the younger generations about the credibility of knowledge that has prevailed for generations. Most of them believe that traditional knowledge is precious, and stress the importance of using it carefully with modern knowledge, without destroying its originality. One young craftsman explained that:

"I have been doing this industry for the last 10 years. I integrated modern techniques, but without spoiling the knowledge we received from our past".

Traditional skills and knowledge have become an attractive and realistic framework for the integration of younger and older generations. Skills classes, ('Guru shilpa panthi') for example, are important for strengthening human assets among young people, while maintaining a 'generational integration'. As clarified by a villager:

"These classes ('panthi') are conducted by the masters ('gurus') of our traditional industries. It is a good platform for younger generations to learn from their traditional masters".

Besides the knowledge they provide, some villagers believe that 'Guru shilpa panthi'are popular, as they help to preserve and transmit not only traditional knowledge, but also the values and customs of their traditional society. As one village respondent noted:

"This is a good approach to encourage young, people's involvement with this traditional industries ('páramparika karmantha'). Some youngsters don't like to follow their fathers, although these traditional industries are descended from their families".

However, the utility of traditional knowledge may vary along with the type/nature of livelihood and a number of other attributes that exist in particular contexts. In this context, traditional knowledge is worthwhile, mainly due to its availability, quality and, specifically, its relevance to the present livelihood activities of the villagers. Hence, traditional knowledge in the Kandyan context, which is practical, pure and original, is the foundation of the villages' human assets.

\section{Labour quality and quantity}

In relation to livelihood analysis, Ellis (2000) and Moser (1998) declare labour as a significant 'asset', emphasising the importance of being free from illness and debilitating health problems. As Moser (1998) notices, household labour is considered as a 'resource' when there is little or no labour market. According to Toulmin (as cited in Ellis, 2000), the large household size has relative 
advantages since it reduces the risks to livelihood security and permits more diverse occupational strategies to be pursued. The issues related to labour are quite different from the conventional relationship between labour and livelihood systems. As emphasised by many villagers, the 'quality' of labour is always a matter of concern, rather than the 'quantity'. Quality labour relates to longterm experiences, outstanding talents and specialised skills and knowledge in their hereditary industries:

"This is not about just crafts. It is all about the talent. We have 'born-talents' and 'skillful-hands' practised from our masters".

A silversmith in another village clarified that:

"You can't value our labour ('shramaya'). We are born with the 'specialised' skills and knowledge that cannot be borrowed from elsewhere".

The quality of labour is related to family ancestry, traditions and knowledge handed down from forefathers. Respondents referred to terms like talented, ('dhaksha') genuine/pure ('niyama'), coming across generations, ('páramparika'), experienced('até-huruwa'), king's people ('rajjuruwange minissu') and reputed ('keerthimath') to describe the 'quality' of their labour. They realise that 'quality labour' is more important than the quantity of the labour force for the continuation and sustainability of their livelihoods (also see Rakodi, 1999). It was a clear fact that most of the households' women are exceptional in their knowledge and skills in particular industries. Women are equally capable as men, and, indeed, some women are more talented in decorating crafts with traditional motifs. Specialised knowledge among female members in households provides a greater security during livelihood vulnerabilities, for example, in case of absence of male labour (due to sickness or death) increasing household reliance on female labour (Daskon, 2010).

\section{Natural capital - the natural environment around people}

In a livelihood context, natural assets are important and often a 'primary' resource, especially to those who derive all or part of their livelihood from natural resource-based activities like farming, fishing, gathering in forests and mineral extraction (DFID, 1999). In a broader sense, natural assets include three components, namely, (i) renewable resources; (ii) non-renewable resources; and (iii) environmental services (Berkes \& Folke, 1992; Throsby, 2001) ${ }^{12}$. According to Costanza et al. (2000), the maintenance of natural capital at or above the current level is the minimum necessary condition for sustainability. The natural capital that rural people depend upon is described as 'common pool resources', as they have limited access to private natural assets. Land and its secure ownership is the most important aspect of natural capital (Rakodi, 1999), and land insecurity severely affects the sustainability of rural livelihood options.

Although natural assets can be many and varied, land was the only resource that respondents explicitly referred to as natural capital in their villages. They all have land entitlements and secure accessibility, but there was no adequate data that clarified the 'contribution' of natural capital (land) to their current livelihoods. As Coomaraswamy (1956) describes, land ownership in these villages is mostly a factor related to its historical cultural context. Most of their lands were given as 'nindagam', the grants given to feudal lords or chieftains and others for service of special merit rendered to the king. Villagers' land tenure is directly related to the nature of services rendered and one's general position in society. Pieris (1956) explains that:

"[It] is always assumed that title was contingent on the performances of 'rájakariya', (services), ranging from formal homage to laborious duties. The 'rájakariya,' attached to land, not the person, and failure to perform 'rajakariya' rendered the land 'purappadu' (abandoned land), and a new claimant was liable to the service attached to the land. Therefore, the land was often given by the king by way of grants called 'sannas'13".

Transect walks and field observations revealed that every village had fairly good natural assets, including, forest, home gardens, accessibility to natural water sources (e.g. rivers and streams) and fertile soil adequate for those who engaged in paddy farming. Land distribution and accessibility depend upon the extent of the villagers' endowments and entitlements. As described by Johnson (1997), ones' ownership “over property varies with one's capabilities, such as human, economic and social assets". In the Kandyan setting, however, access, admission and priority to land entitlement depend upon the villagers' willingness to follow particular norms, traditions and rules of society, and particularly the 'rájakariya' attached to particular families. Among these people, land ownership implies their right to use and benefit from land, but not to rent and sell the land to others and to exclude others from enjoying its benefits or reducing its value. Within these norms, however, 
the villagers' only interest in having secure land was to build a house to live in and to enjoy the feeling that they are 'land owners': "We only want a 'secure place' to live. Thanks to our ancestors, we all have got land and a place to live." Their lands are priceless since they inherited them from their forefathers, and also represent the 'royal patronage' for their excellence in traditional industries. This was explained by a brassworker:

"Our whole family have equal rights to share and use our inherited land for our own purposes, but not to sell. The extent of land we have shows the 'wealthiness' and how our ancestors have been rewarded for their talents".

These comments give an indirect impression of villagers' power, wealth and ancestry, rather than how their land/ natural assets increase/decrease accessibility to other livelihood assets and opportunities.

\section{Financial capital - money that people can use to get more assets}

Financial capital is probably the most 'versatile' asset, but is frequently the one 'least available' to the poor (DFID, 1999). In livelihood analysis, financial assets represent the stock of money and savings in the form of cash, bank deposits or any liquid assets such as livestock and jewellery (Dercon \& Krishnan 1996; DFID, 1999) that people use to achieve their livelihood objectives (Scoones, 1998; Ellis, 2000). Increased accessibility to secure financial resources enables investment in physical capital, like land and equipment that leads to an increase in productivity, while also increasing accessibility to enhanced human capital, such as better health and education (Rakodi, 1999). Therefore, financial capital is particularly important as it can be 'converted' into other types of capital. Financial asset endowments among study communities were relatively smaller than other assets, and accessibility to formal savings, loans and other income sources were limited. One of the significant sources of villages' financial assets noted by study participants included the presence of formal societies such as Craft societies, Co-operative, Welfare, and 'Samurdhi' societies and Farmer organisations. However, these sources of capital and credit are too limited to meet the financial needs and as the majority of the respondents have experienced, there is controversy when prioritising credit recipients. Dependency on particular forms of finance is largely determined by their current livelihoods and the status of other assets in their villages, particularly social and human assets. Instead of relying on such formal sources, as declared by a villager, they have been able to build up secure savings in the form of their 'works' - craft items and the like - to replace savings which were totally depleted during the worst times of the monetary crisis. This is becoming a trend in every village, as an effective and secure form of saving, rather than holding bank accounts or relying on other saving modes, because, as explained by a brassworker:

"Why (would) we rely on others? We have the ability; we can convert some "pieces of our work into money at anytime".

Table 1: Village summaries of the ranking exercise - 'asset relationships'

\begin{tabular}{llllll}
\hline Rank & & & Study villages & \\
\hline & Kiriwaula & Kalapura & Talagune & Embekke & Kalasairigama \\
$1^{\text {st }}$ & Human capital & Physical capital & Social capital & Human capital & Physical capital \\
$2^{\text {nd }}$ & Social capital & Social capital & Human capital & Social capital & Social capital \\
$3^{\text {rd }}$ & Physical capital & Human capital & Financial capital & Physical capital & Human capital \\
$4^{\text {th }}$ & Natural capital & Financial capital & Natural capital & Natural capital & Financial capital \\
& & & & \\
$5^{\text {th }}$ & Financial capital & Natural capital & Physical capital & Financial capital & Natural capital \\
& & & & \\
\hline
\end{tabular}




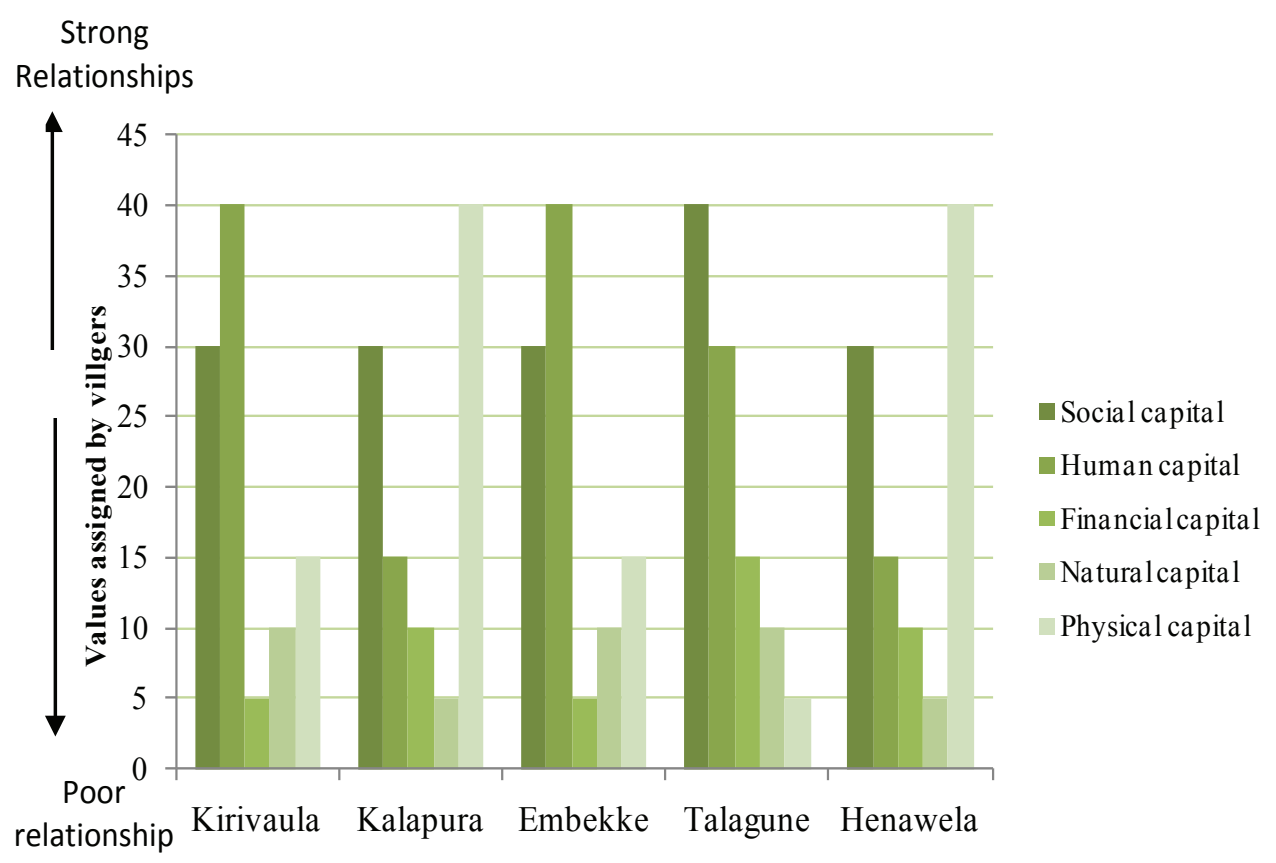

Figure 3: Nature of relationships among culture, traditions and livelihood assets

Source : Field research 2007/2008

The convertibility of their craftwork into money suggests that the traditional or classic forms of products are more appropriate forms of savings:

"If you collect one piece each time you work, it is a huge saving. You can sell them at a time when market value has increased. I can't value the price of the collection that I now have".

Nevertheless, access to informal credit arrangements with relatives, friends, neighbours, village shop keepers and village money lenders was mentioned as a valued asset in all villages. As discussed at the beginning, close family relationships within the village have created trust and social cohesion, which makes possible interestfree money borrowing. About $65 \%-75 \%$ percent of respondenents mentioned that they often borrow money from these informal sources and the main reason behind their choice being explained as follows:

'In our villages, we've known each other for a long time. We all know everyone's requirements as we have been engaging in the same industry. People pay back money soon after they get their stock sold. They never cheat; because, we all have the same aspirations and values".

According to some informal conversations, some village shop keepers also allow customers to owe money for as long as three to four months.

\section{DISCUSSIONS: CULTURAL VALUES, ASSETS RELATIONS AND CULTURAL CAPITAL}

It became clear that the cultural traditions in the context of each village are a significant factor in determining asset ownership and accessibility. Cultural values played an important role, mainly in forming strong social and human capital portfolios in the study villages. The results of the ranking exercise undertaken with village participants explain the importance of each of their livelihood assets according to their relationship with traditional customs, family norms, traditional knowledge and value systems that have been maintained for generations (Table 1 and Figure 3).

As shown in both Table 1 and Figure 3, villagers placed social and human capital in higher ranks, in considering their connectivity with cultural context. However, what is evident from the villagers' perceptions is that there is a stronger relationship between informal social capital and cultural traditions, than between formal social capital and culture. The basis of informal social capital is mostly determined by family traditions, values and ancestral relations, which have been preserved by villagers for many generations. These informal relationships are considered important, not only to preserving their traditional identities, but also in strengthening and securing their assets and to keep 
livelihood activities more sustainable. One craftsman explained this relationship by referring to his village:

"This village is just like our family. In a family we take care of and help each other. There is no jealousy, we are always happy to see everyone's progress, ('diunuwa'), happiness ('sathuta') and prosperity ('samurdhiya'). We work together. These traditional industries ('páramparika karmantha') help us to preserve these social values. They bind us together".

Most of these villages are peaceful and integrated systems that function smoothly, because people trust and help each other. Perhaps the most tangible aspects of 'identity' that are associated with the study villages are the maintenance of strong social relationships, which are bound by longstanding traditions - 'cultural institutions'. Hence, there was a consensus among many respondents that cultural values reinforce their social networks and relationships, hence are social assets. However, in contrast, according to the views of some respondents, cultural traditions are not always effective in increasing either social relations or asset accessibility. Although these respondents have been engaged in the same industry for a long period, have lived in the same village and have been nurtured by the same values and customs, it seems that cultural values have not supported in maintaining strong social assets. Some cultural attributes, such as caste ('kulaya'), have become crucial in determining social integration and relationships among villagers. In some instances, caste has become a matter of 'social exclusion'. As asserted by one female respondent:

"Modern society undervalues our traditional industries ('páramparika karmantha') and, we are ignored as low-caste people ('adu-kula minissu'). But our livelihoods ('jeewanamárga') are designated by our caste ('kulaya'). So, are we less privileged?"

According to another key informant:

"These people have a fear of the future for their children/young generation. In some families, children are not encouraged to carry out their traditional livelihoods, ('páramparika rakiyá' because they believe that these livelihoods are more vulnerable and not suited for the modern society. They force their children to attain a formal education and a 'better' job than their parents had".

According to this explanation, one of the problems of being low-caste ('adu-kula'), is social exclusion, which hinders the access of some sectors to labour and makes it impossible for them to integrate into the society. Thus, cultural values are sometimes blamed for being responsible for their poverty or social deprivation and 'exclusions' (Kliksberg, 1999). Apart from their material difficulties, some villagers face a silent process of 'depreciation' of their values and traditions and hence, their social relationships. As clarified by a villager:

"No such values remain in our village at all. People are chasing only money. All values have gone. People think that money will give you everything and have nothing to do with our traditions ('sampradáyan')".

Depreciating their cultural values means weakening their relationships, collective achievements and associative activities, hence social assets. This also deflates their identity and leads to feelings of low individual and collective self-esteem. The roles played by culture and traditional values in building and securing social assets may vary in different communities and societies. Therefore, in the final analysis, it is important to consider the obstacles associated with traditional values and the way they hinder the opportunities available for people. However, according to the majority of respondents' perceptions, in these particular villages traditional culture has made it easier to set up the extensive participatory form of organisations in which all members are called upon to be actors in solving collective problems, and which function smoothly, thanks to long-standing traditions and value systems. As argued by Matarasso (2000), cultural values were found to have a positive effect on social cohesion by bringing people together, encouraging partnerships, promoting intercultural understanding and neighbourhood security. In addition, in the villages being studied, traditional values help to empower communities by building their organisational skills and capacities and by helping them to gain control over their assets and to become more active. Thus, in the rural Kandyan context, cultural traditions can be regarded as a 'civic virtue' that strengthens villages' solidarity and cohesiveness.

When considered as a whole, $80 \%-90 \%$ of respondents believe that human assets, mainly knowledge and labour, are an ultimate product of their cultural values. There was a consensus among respondents in every village, that cultural traditions are fundamental attributes in reinforcing their knowledge and the skills required for their current livelihoods. The knowledge and skills of these people have mostly been nurtured by ancient Sinhalese-Buddhist customs and their knowledge system represents 'spiritual' meanings, while reflecting their particular interests and modes of life. Ranking 
data revealed that the majority of the respondents in Kiriwaula and Embekke identified a strong relationship between their knowledge, skills, household labour and family traditions. In-depth interviews confirmed that respondents in Henawela and Talagune also believe that culture is the foundation of their current knowledge and skills.

However, some have found that traditional knowledge is becoming less important, and as asserted by a villager in Kalapura:

"The 'only' thing we know is this industry. We can't engage in any other work, as we don't have the 'other' skills required."

This alludes to the disadvantage of relying 'only' on traditional knowledge and the insufficiency of their skills in dealing with present-day life. However, traditional knowledge is regarded as a possible alternative for progress among the world's rural poor (Briggs, 2005) and as Briggs (2008) argues, this can only come about once the validity of traditional/indigenous knowledge has been confirmed. Despite the arguments for the validity of traditional knowledge, what is significant in the rural Kandyan context is that knowledge and skills are considerably enriched by the long-standing traditions, customs and value systems of these people. The data also shows that social relations and family customs secure existing savings and financial flows, whilst helping to maintain effective, tailored, financial assets for the majority of villagers. As long as they are "well trusted, accessible and widely known" (DFID, 1999), informal sources encourage people to continue their financial interactions. Hence, in this context, traditional culture is a 'secondary' institution that facilitates accessibility to secure financial resources. Financial operations are totally dependent on loyalty to their industry and also the personal qualities practised through their traditional systems.

Villagers clearly explained that their lands are inherited and majority of the current land owners are descendants of the early owners and the chief craftsmen, who were rewarded with lands/villages for their royal duties. Most of the families in Kalapura and Henawela are entitled to the lands granted by the government at different stages of the 'Gam Udáwa', the village awakening program. Relationship between physical assets and culture are difficult to explore in detail, since there is no clearly established connectivity between them. However, this relationship can be drawn through certain village programmes implemented by the government (for example see Hennayake, 2006). For example, villagers have gained increased accessibility to infrastructure through the 'Gam Udáwa' programme and, the programme justifies an ideologically essential, politically strategic and 'culturally harmonious' approach to community development. Kalapura is one of the villages developed under the 'Gam Udáwa' and, the focus of infrastructure development has been on revitalising traditional livelihoods, while preserving traditional values, ancient customs and knowledge of the village people. The programme has increased the mobility of villagers and their accessibility to outside institutions, resulting in higher real wages, increased prices for their craft products and more opportunities for other private and public sector jobs, with knock-on effects for the rest of their village economy. Both local and foreign tourists visit their villages and competitive demand for their craft products has increased because of new market links outside Kandy. Hence, the majority of the villagers believe that traditional livelihoods and their cultural values have become important in the provision of infrastructure in their villages. As stated by one respondent: "The government has shown its concern for our traditional industries and the importance of preserving them for the future". The 'Gam Udáwa' scheme presents a combination of traditional and modern aspects and is an attempt to harmonise rural and urban, past and present, and traditional and modern domains. Despite the economic difficulties generally experienced by every village community, there is a consensus among respondents that 'Gam Udáwa' represents the government interest in investing in traditional culture and strengthening the sustainable livelihoods of those who depend on traditional activities for their living.

However, both land endowments and entitlements are factors considerably dependent upon "norms of legitimacy, which are reinforced by formal and informal institutions in society" (Johnson, 1997). The present generations in these villages are proud 'owners' of these royal grants and, as many villagers asserted, their secure ownership of land and accessibility is facilitated through their family ties and customs. Specifically, among extended families in Kiriwaula and Embekke, there is a strong sense of secure land ownership and the division and selling of land is prohibited. They keep their inherited lands as 'common property' among the family members, in the sense that no-one owns or controls the land independently. A contrasting situation is apparent in the comments of a respondent in Kiriwaula:

"My brother sold a piece of land to outsiders ('pitagam-kárayo'). For the first time, our land was divided, which is against our family customs. We were worried, as he sold our ancestral property to an outsider". 
An important aspect of these villagers' property is that it reflects the value of their inherited ownership and accessibility, through which they can claim secure asset entitlements. However, economically induced changes may affect their inherited ownership ('parampará aythiya') and sometimes land entitlements are even lost. Those who are struggling with economic difficulties may be forced to sell a piece of land irrespective of their 'family customs'. This does not mean they are 'disrespecting their family values but according to one respondent: "What do we gain by preserving our family 'heritage', if we don't get adequate income". Therefore, it is reasonable to conclude that traditions and cultural norms may control resource accessibility to some extent, though it is relatively insignificant in Kandyan society compared with other settings ${ }^{14}$. In this context, the claim to inherited and 'secure' entitlement and accessibility to land is always a matter of prestige. Pointing to the interconnectivity between culture and natural capital, Throsby (2001) and Gadgil (1987) argue that both culture and natural assets are rich in 'diversity', and hence, their relationship is crucial in attaining and maintaining a secure and sustainable livelihood system. In this sense, culture, traditions and land resources are connected and they impose a 'duty of care' (Throsby, 2001) on the present generation in the interests of sustainability.

The evidence demonstrates the status of asset portfolios of the study villages and how asset availability, quality and accessibility vary, and their relationships with traditional culture - knowledge, skills, norms, customs and cultural values possessed by village communities. It was clear from the village examples that people have different perceptions of culture and traditional value systems according to the way they engage and benefit from culture. However, this paper revitalises present livelihood analyses, where culture is rather neglected and situated as a constraint that controls livelihood opportunities of rural communities. A comprehensive assessment of livelihood assets provides an accurate and realistic account of the strengths and resource endowments of rural communities and how these people attempt to convert their own capacities into various livelihood outcomes. Villagers appear to be occupied with the maintenance of a range of cultural practices and traditions that are valued for reinforcing their asset ownership. Cultural values can be the basis for the maintenance and enhancement of each of asset, and through fostering certain forms of value maintenance and particular patterns of social relationships and interactions, they enable, aspire and indeed empower. Thus, culture can possibly be referred to as an 'asset', which represents inherited ingenuities, traditions, values, ideologies, rituals, beliefs and knowledge systems and, also, all spiritual, aesthetic, historical, symbolic and authentic expressions of village people. In this context, culture also embodies community identities, which are a "treasure of self-fulfilment" (UNESCO, 1982) and more importantly, the "living practices', traditions and knowledge, which are vigilantly preserved and transmitted across generations. Findings in the study villages confirm that culture and traditions are 'living assets', which are necessary to maintain essential life-support systems of communities (Cheiesura $\&$ de Groot, 2003). Like many other forms of livelihood assets, culture is both convertible (Bourdieu,1986) and can be used for 'other purposes'. Cultural inheritance can be converted into social resources and the cultural values these people have accumulated from their birth are 'spent' to meet different needs at different times. What is more important, in the rural context, is that cultural values are complementary to other forms of capital and enhance productivity and efficiency by reducing transaction costs. Thus, culture is a form of asset that will clearly be incorporated within the livelihood framework. A deep respect for such cultural values and traditions will enhance favourable conditions for making use of existing resources, capacities and accumulated knowledge, traditions and value systems. Sometimes, people may not have material wealth, but they do have a rich store of cultural values, as the research has seen, that often goes back for hundreds of years. This paper hopefully offers a new perspective on culture-livelihood discussions, by not only emphasising the significance of 'cultural sensitivity' (Commonwealth Foundation, 2008), but by providing some guidance on the way researchers might move forward in investigating the functions performed by different cultural systems.

Above discussion indicated the way that cultural values influence people to choose their livelihood options similarly and more positively, in ways which help them to understand and respect each other. Local people are aware of their values and, as clarified by one villager; "our culture and traditional values are 'living' and vital for the continuation of society". Hence, the reasons for claiming culture in a capital sense are not hard to justify through the Kandyan communities, and as further suggested by one villager;

"we must understand our culture and traditions as a precious resource ('vatina sampathak') -that supplies the nerve and the urge for our survival".

In order to bring culture into operational level, a concept like cultural capital ${ }^{15}$ is complementary and adequately embraces the diversity and uniqueness of traditions and cultural values. It is appropriate to ask, 'what is 'cultural capital' in the livelihood context?', and 
'what cultural capital does significantly offer compared to other capital assets?' make distinctive compared to other capital assets?' (Daskon, 2011). In this paper cultural capital means the wealth created through celebrating and investing in cultural histories, values, traditions, rituals and ideologies of communities. In order to define culture as a livelihood capital, the paper enquires into the fundamental elements/attributes that are core to cultural capital, based on the field research findings. Considering field research findings, the author believes that the idea of cultural capital may vary according to the significance of culture and traditional values in different societies and communities, in terms of people's engagement with cultural activities and benefits received from their cultural values. In a livelihood context, cultural capital can be understood through UNFPA's (2008) interpretation of culture.

"Culture is made up of "inherited patterns of meanings that people share within particular contexts'. Through socialisation, people develop common understandings of what is significant and what is not. These common understandings, which may be reflected in symbols, values, norms, beliefs, relationships and different forms of creative expressions', influence how people 'manage their daily work, large and small'; they 'shape the way things are done and understanding of why they should be done so'; they 'provide the lens through which people interpret their society".

It was clear from the Kandyan examples that people have different perceptions about cultural traditions and value systems according to the way they 'engage' and 'benefit' from culture. It is still meaningful to consider the 'relative' usefulness of particular cultural entities in different societies in relation to their livelihood choices. As indent, cultural capital can be established in the Kandyan villages by considering the extent to which cultural values influence people's livelihood choices, asset ownership, accessibility and livelihood resilience.

\section{CONCLUSION}

In elaborating on the point that people's assets give meaning to their world, this paper attempted to justify that culture is a rural asset, which represents power to act and reproduce, challenge or change the rules that govern the use and transformation of resources in a livelihood context. The ways in which rural villagers' livelihoods composed are multiple and they have significant traditional components, which considerably facilitate their resource accessibility. Culture facilitates accessibility to other assets, providing direct consumption opportunities. For rural communities, culture is an indispensable resource.

"Neglecting our cultural traditions is a mistake that we all have been doing. We survive with our inherited resources. Our traditional knowledge and skills are the nerve of our lives" (villager Kalapura).

Thus, cultural tradition is, almost 'naturally' given asset and an 'inherited resource from thepast' (Appadurai,1981). In these village contexts, culture is more aligned with intangible aspects, which are less directly ascribable, but are critical for the well-being and sustainability of livelihoods (UNESCO, 2003). A significant problem is that the peoples' 'inherent' ingenuities have not been sufficiently taken into consideration. Many livelihood initiatives have failed to appreciate the dynamic and interactive nature of the local cultural context in which most rural livelihood systems function. This paper hopefully sheds light towards understanding how rural communities construct their asset portfolios through intangible cultural values which have been present for generations, facilitating and securing various asset entitlements and accessibility. The idea of cultural capital offers a pathway towards embracing culture in a livelihood concern. There is no doubt that these villages are rich and unique in cultural values, but the significance of culture as a fundamental resource, or as this paper proposes, a type of 'asset', may not be equally evident and valid for every rural society. Therefore, the changing compositions of cultural context in different societies results in different inputs and outputs and they may seem sustainable at certain points and not at others. However, taking culture as a resource helps to internalise cultural values as a part of rural development interventions and minimise the difficulties of monitoring invisible cultural aspects, which has often led to an underestimation and misunderstanding of some cultures. Such a proposition of culture as an asset encompasses all tangible aspects and intangible values embedded in human society and provides a robust source for a sustainable life-support system of the rural communities.

\section{END NOTES}

${ }^{1}$ This paper focuses only on social, human, natural and financial capital considering the analytical significance to the present context. Physical capital is not analysed due to inadequate information, particularly regarding the relationship between physical capital and cultural values in the study villages.

2 Brundtland Commission in 1987, Agenda 21 of the United Nations Conference on Environment and De- 
velopment (UNCED) in 1992, the Copenhagen Declaration in 1995 and the Fourth World Conference on Women (FWCW) in Beijing have given major considerations of the concept of livelihood and 'sustainable livelihoods'.

${ }^{3}$ (i) Knox, R. (1681) Historical relations of the Island of Ceylon in the East Indies, London: Richard Chiswell; (ii). D’Oyley, Sir. J. (1929) (ed.) A sketch of the constitution of the Kandyan kingdom, IL.J.B Turner, Colombo: Ceylon government press; (iii) Gieger, W. (1950) trans., (ed.) Mahawamsa: the great chronicles of Ceylon, Ceylon government information department.

4 'Pattal-hatara' consists of: (i) Abarana pattala jewellery workshop, (ii) Otunu pattala - crown workshop, (iii) Rankadu pattala - golden sword workshop and (iv) Simhasana pattala - lion throne workshop.

5 The procession associated with the Daladá Máligawa, the Temple of the Tooth Relic in Kandy is known as the 'Dálada Perahara'.

6 A purposive sample is a sample selected in a deliberative and non-random fashion to achieve a certain goal.

7 Vertical [patron/client] and horizontal [between individuals with shared interests] interconnectedness increase people's trust and ability to work together and expand their access to wider institutions, such as political or civic bodies.

8 Fomalised groups often entails adherence to mutually agreed or commonly accepted rules, norms and sanctions.

9 Trust, reciprocity and exchanges facilitate cooperation, reduces transaction costs and may provide the basis of informal safety nets among the poor.

10 'Attam' is a traditional arrangement which operates normally among the rural farming communities, providing labour assistance by pooling the labour of a group of cultivators/farmers.

11 Intricate motifs such as, tundan veda (geometrical nature); usamba-kunjara (bull-elephant): nava-nári-kunjara (nine-women-elephant).

12 Renewable resources (i.e., fish, wood and drinking water) are produced and maintained by the processes and functions of ecosystems. Non-renewable re- sources (i.e. oil and minerals) are extracted from ecosystems. Environmental services (i.e. maintenance of the quality of the atmosphere, climate, operation of the hydrological cycle including flood control and drinking water supply, waste assimilation, recycling nutrients, generation of soil, pollination of crops, provision of food from the sea and the maintenance of the genetic library).

13 'Sannas' are records of donations: There were three main types of grants that were given by the king; Nindagam, Viháragam and Deválagam.

14 When compared to Sri Lanka, in some African and Asian contexts, cultural attributes such as class, caste and gender exert intense control on resource entitlements [see Francis, E. (1998) 'Gender and Rural Livelihoods in Kenya', Journal of Development Studies, 35(2), pp: 72-95; Jackson, C. (2003) 'Gender Analysis of Land: Beyond Land Rights for Women', Journal of Agrarian Change, 3(4), pp: 453- 428].

15 The concept of cultural capital was first introduced by French sociologist Pierre Bourdieu in three forms, which include - embodied form, objectified form and institutionalised form [see Bourdieu (1986)]. However, there is no clear reference to cultural capital in livelihood analysis.

\section{REFERENCES}

Adato, M. \& Meinzen-Dick, R. (2002) Assessing the impact of agricultural research on poverty using the sustainable livelihoods framework, Discussion Paper, International Food Policy Research Institute.

Appadurai, A. (1981) Past as a scarce resource, Man, 16(2), pp: 201-219.

DOI: http://dx.doi.org/10.2307/2801395

Bagchi, D. K., Blaikie, P., Cameron, J., Chattopadhyay, M., Gyawali, N. \& Seddon, D. (1998) Conceptual and methodological challenges in the study of livelihood trajectories: case-studies in eastern India and western Nepal, Journal of International Development, 10, pp: 453-468.

DOI:http://dx.doi.org/10.1002/(SICI)10991328(199806)10:4< 453::AID-JID538>3.0.CO;2-Q

Bebbington, A. (1999) Capitals and capabilities: a framework for analysing peasant viability, rural livelihoods and poverty, World Development, 27(12), pp: 2021 - 2044.

DOI: http://dx.doi.org/10.1016/S0305-750X(99)00104-7

Berkes, F. \& Folke. C. (1992) A system perspective on the interrelations between natural, human-made and cultural 
capital, Ecological Economics, 5(1), pp: 1-8. DOI: http://dx.doi.org/10.1016/0921-8009(92)90017-M

Bond, R. \& Mukherjee, N. (2002) Livelihood asset status tracking - an impact monitoring tool?, Journal of International Development, 14 (6), pp: 805-815.

DOI: http://dx.doi.org/10.1002/jid.926

Bourdieu, P. (1986) The forms of capital, in J. G. Richardson ed. Handbook of theory and research for Sociology of education, New York: Greenwood Press, pp: 241-258.

Brennan M. A., Flint, C. G. \& Luloff, A. E. (2009) Bringing together local culture and rural development: findings from Ireland, Pennsylvania and Alaska, Sociologia Rurails, 49 (1), pp: $97-112$.

DOI: http://dx.doi.org/10.1111/j.1467-9523.2008.00471.x

Briggs, J. (2005) The use of indigenous knowledge in development: problems and challenges, Progress in Development Studies, 5(2), pp: 99 -114.

DOI: http://dx.doi.org/10.1191/1464993405ps105oa

Briggs, J. (2008) Indigenous knowledge and development, in V. Dasai \& R. B. Potter eds. The Companion to Development Studies, London: Hodder Education, pp: 107-111.

Brockington, D. \& Sullivan, S. (2003) Qualitative research, in R. Scheyvens \& D. Storey eds. Development Fieldwork: A Practical Guide, London: Sage, pp: 57 - 77.

DOI: http://dx.doi.org/10.4135/9781849208864.n4

Brow, J. (1999) Utopia's new-found space: images of the village communities in the early writings of Ananda Coomaraswamy, Modern Asian Studies, 33(1), pp: 67-86.

DOI: http://dx.doi.org/10.1017/S0026749X9900308X

Cahn, M. (2002). Sustainable livelihood approach, 3rd Biennial Conference of the International Development, Institute of Development Studies, Massey University, New Zealand.

Carney, D. (1998) Sustainable Rural Livelihoods; what contribution can we make?, London: Department for International Development (DFID).

Chambers, R. \& Conway G. (1991) Sustainable Rural Livelihoods: practical concept for the 21st century, Discussion paper 296, Brighton, Institute of Development Studies (IDS).

Chambers, R. (1998) Challenging the Professions: Frontiers for rural development, London: International Technology Publications.

Chiesura, A. \& de Groot, R. (2003) Critical natural capital: a socio-cultural perspective, Ecological Economics, 44(2-3), pp: 219-231.

DOI: http://dx.doi.org/10.1016/S0921-8009(02)00275-6

Commonwealth Foundation (2008) Putting Culture First: commonwealth perspectives on culture and development, London: Commonwealth Foundation
Coomaraswamy, A. (1956) Mediaeval Sinhalese Art, USA: Pantheon Books.

Costanza, R., Daly, H., Folke, C., Hawken, P., Holling, C. S., McMichael, A. J, Pimentel, D. and Rapport, D. (2000) Managing our environmental portfolio, BioScience, 50 (2), pp: 149-155. DOI: http://dx.doi.org/10.1641/0006-3568(2000)050[0149:MO $\mathrm{EP}] 2.3 . \mathrm{CO} ; 2$

Costanza, R. \& Daly, H. (1982) Natural capital and sustainable development, Conservation Biology, 6(1), pp: 37-46. DOI: http://dx.doi.org/10.1046/j.1523-1739.1992.610037.x

Crick, M. (1994) Resplendent sites, discordant voices: Sri Lankans and international tourism, Switzerland: Harwood Academic Publishers.

Daskon C. D. (2010) Cultural resilience: the roles of cultural traditions in sustaining rural livelihoods, Sustainability 2010, (2), pp: 1080-1100.

Daskon C. D. (2011) Cultural traditions and sustainable rural livelihoods - a case study from the Kandyan villages, central Sri Lanka, Germany, Lambert Academic Publishers.

de Haan, L. J \& Zoomers, A. (2003) Development geography at the crossroads of livelihood and globalization, Tijdschrift voor Economische en Sociale Geografie, 94(3), pp: 350-362.

DOI: http://dx.doi.org/10.1111/1467-9663.00262

de Haan, L. J. (2000) Globalization, localization and sustainable livelihoods, Sociologia Ruralis, 40( 3), pp: 341-365.

DOI: http://dx.doi.org/10.1111/1467-9523.00152

Department For International Development (DFID) (1999) Sustainable livelihood guidance sheet, London: Department for International Development.

Department For International Development (DFID) (2001) Sustainable Livelihoods Guidance Sheet, London: Department for International Development [online] Available at: < http:// www.ennonline.net/pool/files/ife/section6.pdf $>$ [Accessed January, 2009].

Department of Census and Statistics (2001) Census of Population and Housing - 2001 Sri Lanka - KANDY district report, Colombo: Department of Census and Statistics.

Department of Census and Statistics (2006/07), Household Income and Expenditure Survey, [online] Available at: < http:// www.statistics.gov.lk/HIES/HIES2006_07Website/index.htm Rretrived 21 January 2009> [Accessed January, 2011].

Dercon, S. \& Krishnan, P. (1996) Income portfolios in rural Ethiopia and Tanzania: choices and constraints, Journal of Development Studies, 32(6), pp: 850-875.

DOI: http://dx.doi.org/10.1080/00220389608422443

Duncan, J. S. (1990) The city as text: the politics of landscape interpretation in the Kandyan kingdom, Cambridge: Cambridge University Press. 
Eames P. (2006) Cultural wellbeing and cultural capital - art participation New Zealand, Waikanae, PSE consultancy.

Ellis, F. \& Biggs, S. (2001) Evolving themes in rural development 1950s-200s', Development Policy Review, 19(4), pp: $437-448$.

DOI: http://dx.doi.org/10.1111/1467-7679.00143

Ellis, F. (2000) Rural livelihoods and diversity in developing countries, London: Oxford University Press.

Flick, U. (2006) An introduction to qualitative research, London: Sage.

Gadgil, M., Berkes, F. \& Folke, C. (1993) Indigenous knowledge for biodiversity conservation, Ambio, 22, pp: 151-156.

Gadgil, M. (1987) Diversity: cultural and biological, Trends in Ecology and Evolution, 2(12), pp:369-373.

DOI: http://dx.doi.org/10.1016/0169-5347(87)90138-8

Glavovic, B., Scheyvens, R. \& Overton, J. (2002) Waves of adversity, layers of resilience: exploring the sustainable livelihoods approach, 3rd Biennial Conference of the International Development, Institute of Development Studies, Massey University, New Zealand, DEVNET Conference.

Hennayake, N. (2006) Culture, politics and development in postcolonial Sri Lanka, Oxford: Rowman \& Littlefield Publishers Inc.

Jenkins, T. N. (2000) Putting postmodernity into practice: endogenous development and the role of traditional cultures in the rural development of marginal regions, Ecological Economics 34, pp: 301-314

DOI: http://dx.doi.org/10.1016/S0921-8009(00)00191-9

Johnson, C. (1997) Rules, norms and the pursuit of sustainable livelihoods, IDS working paper, Brighton: Institute of Development Studies (IDS).

Karunanayake, M. M. (1979) Traditional exchange - labour in hill country Sri Lanka - a study of the attam institution, Sri Lanka Journal of Social Sciences, 2(1), pg:109-119

Kliksberg, B. (1999) Social capital and culture: master keys to development, CEPAL review, 69, pp: 83-102.

Leach, E. R. (1961) Pul Eliya, a village in Ceylon; a study of land tenure and kinship, Cambridge: Cambridge University Press.

MacDonald, R. M. \& Jolliffe, L. (2002) Cultural rural tourism: evidence from Canada', Annals of Tourism Research, 30(2), pp: 307-322.

DOI: http://dx.doi.org/10.1016/S0160-7383(02)00061-0

Matarasso, F. (2000) Developing understanding of the social impact of the arts, Culture-link (Special issue on culture and development vs. cultural development), pp: 51-58.
Miles, M. \& Huberman, A. (1994 ) Qualitative Data Analysis, London: Sage.

Moore, M. (1989) The ideological history of the Sri Lankan peasantry, Modern Asian Studies, 23(1), pp: 179-207.

DOI: http://dx.doi.org/10.1017/S0026749X00011458

Morris, M. (1998) 'Social capital and poverty in India', IDS Working Paper 61, Brighton: Institute for Development Studies (IDS).

Moser, C. O. N. (1998) 'The asset vulnerability framework: reassessing urban poverty reduction strategies', World Development, 26(1), pp: 1 -19.

DOI: http://dx.doi.org/10.1016/S0305-750X(97)10015-8

Narayan, D. \& Pritchett L. (1997) Cents and sociability: houesold income and soical capital in rural Tanzania', Economic Development and Cultural Change, 47(4), pp: 871 - 897.

DOI: http://dx.doi.org/10.1086/452436

Pasteur, K. (2001) Tools for sustainable livelihoods: livelihoods monitoring and evaluation, IDS Working Paper, Brighton: University of Sussex, Institute of Development Studies (IDS).

Pieris, R. (1956) ed. Some aspects of traditional Sinhalese culture: A symposium, Ceylon University Conference on Traditional Culture, University of Peradeniya, Sri Lanka.

Putnam, R. (2000) Bowling alone: the collapse and revival of American community, New York: Simon and Schuster.

DOI: http://dx.doi.org/10.1145/358916.361990

Rakodi, C. (1999) A capital asset framework for analysing household livelihood strategies: implications for policy, Development Policy Review, 17, pp: 315-342.

DOI: http://dx.doi.org/10.1111/1467-7679.00090

Rao, V. \& Walton, M. (2004) Culture and public action: relationality, equality of agency, and development, in V. Rao \& M. Walton eds. Culture and public action, California: Stanford University Press, pp: 3-15.

DOI: http://dx.doi.org/10.1596/0-8047-4787-3

Schech, S. \& Haggis, J. (2000) Culture and development: a critical introduction, Oxford: Blackwell Publishers Inc.

Scoones, I. (1998) Sustainable rural livelihoods: a framework for analysis, IDS, Working Paper, Brighton: Institute of Development Studies (IDS).

Seneviratne, A. (1983) Kandy, Colombo: Central Cultural Fund, Ministry of Cultural Affairs Sri Lanka.

Senevirathne, H. L. (1978) Rituals of the Kandyan state, Cambridge: Cambridge University Press.

Shivakoti, G. \& Shrestha, S. (2005) Analysis of livelihood asset pentagon to assess the performance of irrigation systems: 
part 1 - Analytical Framework, Water International, 30, pp: 356-362.

DOI: http://dx.doi.org/10.1080/02508060508691876

Sreedevi, T. K. (2005) Livelihood analysis in Powerguda and Kistapur micro-watersheds in southern India, International Crops Research Institute for the Semi-Arid Tropics (ICRISAT) [online] Available at: <http://www.icrisat.org/Biopower/ SreedeviLivelihoodAnalysis.pdf $>$ [Accessed January, 2009].

Thilakasiri, J. (1994) Survey of traditional craft villages and families descended from traditional craftsmen of Sri Lanka, Colombo: S. Godage and Brothers.

Throsby, D. (2001) Economics and culture, Cambridge: Cambridge University Press.

Toner, A. (2003) Exploring sustainable livelihoods approaches in relation to two interventions in Tanzania, Journal of International Development, 15, pp: 771-781.

DOI: http://dx.doi.org/10.1002/jid.1030

Tucker, V. (1999) The myth of development: a critique of a Eurocentric discourse, in Ronaldo Munck \& Denis
O'Hearn eds. Critical Development Theory, London, Zed Books, pp:1 - 25.

UNESCO (1982) Mexico City Declaration on Cultural Policies, Article 10, Paris: UNESCO [online] Available at: <http:// portal.unesco.org/culture/en/files/12762/11295421661mexico_ en.pdf/mexico_en.pdf $>$ [Accessed January, 2009].

UNESCO (2001) World Cultural Report, Paris: UNESCO.

UNESCO (2003) Convention for the safeguarding of the intangible cultural heritage, Paris: UNESCO [online] Available at: $<$ http://www.unesco.org/culture/ich/index.php $>$ [Accessed April, 2008].

UNFPA - United Nations Population Fund (2008) State of world population: reaching common ground - culture, gender and human rights, United Nations Population Fund (UNFPA).

Uphoff, N. \& Wijayaratna C. M. (2000) Demonstrated Benefits from social capital: the productivity of farmer organizations in Gal Oya, Sri Lanka', World Development, 28, pp: 1875-1890. DOI: http://dx.doi.org/10.1016/S0305-750X(00)00063-2 